\title{
Transcriptional and Posttranscriptional Regulation of Tumor Necrosis Factor Gene Expression in Human Monocytes
}

\author{
Eric Sariban, Kyoko Imamura, Robert Luebbers, and Donald Kufe \\ Laboratory of Clinical Pharmacology, Dana-Farber Cancer Institute, Harvard Medical School, Boston, Massachusetts 02115
}

\begin{abstract}
Regulation of tumor necrosis factor (TNF) gene expression was investigated in resting human monocytes and in 12-Otetradecanoylphorbol-13-acetate (TPA) activated monocytes. TNF transcripts were undetectable in resting monocytes. However, in TPA-activated monocytes, TNF mRNA was first detectable by $3 \mathrm{~h}$ and reached maximal levels by $12 \mathrm{~h}$ of drug exposure. Using run-on transcription assays, the TNF gene was transcriptionally inactive in resting monocytes, but was rapidly activated after TPA exposure. The protein synthesis inhibitor, cycloheximide (CHX), had no detectable effect on levels of TNF transcripts in resting monocytes, while this agent superinduced the level of TNF mRNA by 50 -fold in TPA-activated cells. TPA activated monocytes were also exposed to actinomycin $\mathrm{D}$ and/or $\mathrm{CHX}$ to determine whether transcriptional or posttranscriptional control of TNF gene expression was responsible for the induction of TNF transcripts. After $1 \mathrm{~h}$ of actinomycin $D$ treatment, the amount of TNF transcripts was reduced by $\mathbf{7 5 \%}$. In contrast, no difference in TNF mRNA levels was observed in TPA-activated monocytes exposed to $\mathrm{CHX}$ alone or $\mathrm{CHX}$ in combination with actinomycin D. These findings indicated that $\mathrm{CHX}$ prevented the degradation of TNF mRNA by inhibiting the synthesis of a labile protein. Run-on transcription assays performed on cells exposed to either TPA or the combination of TPA and CHX further indicated that $\mathrm{CHX}$ treatment increased transcription of the TNF gene. Thus, TNF gene expression is controlled at the transcriptional level in resting human monocytes, while both transcriptional and posttranscriptional events regulate the level of TNF transcripts in TPA-activated cells.
\end{abstract}

\section{Introduction}

Monocytes can be activated in vitro to exhibit cytolytic activity against malignant cells (1). The induction of monocyte tumoricidal activity may involve both cell contact and the secretion of distinct cytotoxic substances (1). Tumor necrosis factor alpha (TNF-alpha) ${ }^{1}$ has been described as a tumoricidal

Address reprint requests to Dr. Sariban, Laboratory of Clinical Pharmacology, Dana-Farber Cancer Institute, 44 Binney Street, Boston, MA 02115.

Received for publication 10 July 1987 and in revised form 13 October 1987.

1. Abbreviations used in this paper: ACT, actinomycin D; CHX, cycloheximide; TNF, tumor necrosis factor; TPA, 12-O-tetradecanoylphorbol-13 acetate.

J. Clin. Invest.

(c) The American Society for Clinical Investigation, Inc.

0021-9738/88/05/1506/05 \$2.00

Volume 81, May 1988, 1506-1510 protein secreted by interleukin 1 , interleukin 2 , gamma-interferon or endotoxin-activated monocytes (2-4). In contrast, circulating monocytes neither exhibit cytotoxic activity nor produce TNF, thus indicating that these functions are induced by certain stimuli (4-6).

Treatment of human monocytes with 12-O-tetradecanoylphorbol-13 acetate (TPA) induces further differentiation of these cells along the macrophage pathway. For example, TPA phosphorylates the complement receptor CRl on monocytes that enables these cells to mediate phagocytosis (7). Certain protein products of activated macrophages increase after exposure of resting monocytes to TPA. These products include plasminogen activators that function as proteolytic enzymes in tissue destruction (8) and PDGF-like proteins that act as mediators of inflammation (unpublished observations). In addition, an increase in cytotoxic activity has also been found in TPA-treated monocytes (9). Thus, TPA-treated monocytes may be useful as a model of activated macrophages.

We have studied the regulation of TNF gene expression in both resting and TPA-activated human monocytes. We report that TNF gene expression is primarily regulated at the transcriptional level in resting monocytes, while both transcriptional and posttranscriptional mechanisms regulate the level of TNF transcripts in TPA-activated monocytes.

\section{Methods}

Cell and cell culture. Peripheral blood monocytes were obtained from normal blood donors. Monocytes were isolated from plateletpheresis byproducts after Ficoll-Hypaque gradient sedimentation and adherence to plastic culture flasks for $30 \mathrm{~min}$ at $37^{\circ} \mathrm{C}$ in the presence of $5 \%$ pooled human $\mathrm{AB}$ serum. Nonadherent cells were removed by vigorous washings with PBS. The remaining adherent cells were designated as the freshly isolated (activated) monocytes. The adherent cells were further incubated for 24-48 h in RPMI 1640 medium containing 10\% fetal bovine defined serum (Hyclone Laboratories, Logan, UT). At that time, most of the deactivated or resting monocytes were detached from the flasks. All media were supplemented with $2 \mathrm{mM}$ L-glutamine and $1 \%$ penicillin/streptomycin.

TPA (33 nM), bacterial lipopolysaccharide (LPS, $1 \mu \mathrm{g} / \mathrm{ml}$ ), cycloheximide (CHX;10 $\mu \mathrm{g} / \mathrm{ml}$ ) and actinomycin D (ACT; $5 \mu \mathrm{g} / \mathrm{ml}$ ) were added to the monocyte preparations as indicated in the figure legends.

Isolation and analysis of total cellular RNA. Total cellular RNA was isolated using the guanidine thiocyanate cesium chloride method (10) and analyzed as described (11). Ethidium bromide staining of the agarose gels before blotting revealed the presence of equal amounts of RNA. Transcripts were visualized by autoradiography after hybridization to the following ${ }^{32} \mathrm{P}$-labeled probes: $(a)$ the PE4 plasmid containing a 1.7-kb Pst I/Bam HI TNF cDNA insert (12); and (b) the chicken beta actin pAl plasmid (13).

Run-on transcription assay. For transcriptional studies, $10^{8}$ cells were pelleted at $500 \mathrm{~g}$ for $5 \mathrm{~min}$ and then washed twice with ice-cold PBS. The cell pellet was resuspended in $10 \mathrm{ml}$ of lysis solution $(10 \mathrm{mM}$ Tris $\mathrm{HCl}, \mathrm{pH} 7.4,2 \mathrm{mM} \mathrm{MgCl}, 3 \mathrm{mM} \mathrm{CaCl}_{2}, 3 \mu \mathrm{M}$ DTT, $0.3 \mathrm{M}$ sucrose, and $0.5 \%$ Triton $\mathrm{X}-100$ ) and disrupted in a loosely fitted Dounce homogenizer. The nuclei were centrifuged at $25,000 \mathrm{rpm}$ for 
$60 \mathrm{~min}$ at $4^{\circ} \mathrm{C}$ through a $2.3-\mathrm{M}$ sucrose cushion containing $0.5 \%$ Triton X. The nuclei pellet was either frozen at $-70^{\circ} \mathrm{C}$ in $40 \%$ (vol/vol) glycerol, $50 \mathrm{mM}$ Tris $\mathrm{HCl}$, pH $8.3,5 \mathrm{mM} \mathrm{MgCl}$ and $0.1 \mathrm{mM}$ EDTA or incubated immediately for $30 \mathrm{~min}$ at $27^{\circ} \mathrm{C}$ in $330 \mu$ l of transcription mixture (20 mM Tris $\mathrm{HCl} \mathrm{pH} \mathrm{8.3,100} \mathrm{mM} \mathrm{KCl,} 4.5 \mathrm{mM} \mathrm{MgCl}, 0.4$ $\mathrm{mM}$ each of ATP, CTP, and GTP, $2 \mathrm{mM}$ DTT, $20 \%$ (vol/vol) glycerol, and $200 \mu \mathrm{Ci}$ of [alpha- ${ }^{32} \mathrm{P}$ ]UTP ( $>760 \mathrm{Ci} / \mathrm{mmol}$; Amersham Corp.). Transcription was terminated by the addition of $40 \mu \mathrm{g} / \mathrm{ml}$ DNAse I, 10 $\mathrm{mM}$ Tris-HCl, pH 8.4, $100 \mathrm{mM} \mathrm{NaCl}, 1 \mathrm{mM}$ EDTA and $150 \mathrm{U} / \mathrm{ml}$ RNAsin for $15 \mathrm{~min}$ at $26^{\circ} \mathrm{C}$. Proteinase $\mathrm{K}(750 \mu \mathrm{g} / \mathrm{ml})$ and SDS (1\%) were then added for $30 \mathrm{~min}$ at $37^{\circ} \mathrm{C}$. Nuclear RNA was isolated by phenol/chloroform extractions and then ethanol precipitated several times in $2.5 \mathrm{M}$ ammonium acetate.

Labeled nuclear RNA was hybridized to linearized DNA probes $(5$ $\mu \mathrm{g})$ immobilized to nitrocellulose filters using a dot-blot apparatus. Alternatively, linearized plasmids DNA $(5 \mu \mathrm{g})$ were run in a $1 \%$ agarose gel and transferred to nitrocellulose filters by Southern blotting. Filter prehybridization was performed in $5 \times$ Denhardt's solution, $40 \%$ formamide, $4 \times$ SSC, $5 \mathrm{mM}$ EDTA, $0.4 \%$ SDS and $100 \mu \mathrm{g} / \mathrm{ml}$ yeast tRNA for a minimum of $2 \mathrm{~h}$. The labeled RNA was then heated at $80^{\circ} \mathrm{C}$ for $10 \mathrm{~min}$ in hybridization buffer (same as prehybridization buffer, except for $2 \times$ Denhardt's), chilled in ice and hybridized (minimum of $10^{6}$ $\mathrm{cpm}^{32} \mathrm{P}$-labeled RNA/ml hybridization buffer) to the following DNAs: (a) the chicken beta actin pA1 plasmid (13); (b) the JW102 plasmid carrying a human beta globin gene (14); (c) the PE4 plasmid carrying the human TNF alpha gene (12); and (d) the 6.7-kb Bam HI/Sal I fragment of the human c-src-1 plasmid (15).

Measurement of TNF protein production. TNF protein concentrations in monocyte supernatants were determined by an ELISA that utilizes two different monoclonal antibodies reactive with distinct epitopes on the TNF molecule (16). Biological activity was determined in the mouse L-929 cell cytotoxicity assay standardized with recombinant TNF. L-cells $\left(5 \times 10^{4} /\right.$ well $)$ sensitive and resistant to the cytotoxic effects of TNF were incubated in the presence of $0.1 \mu \mathrm{g} / \mathrm{ml}$ actinomycin $D$ for $18 \mathrm{~h}$ (17). The cells were fixed and stained with $0.5 \%$ crystal violet in $20 \%$ methanol. After $10 \mathrm{~min}$, the plates were washed and the dye released with $33 \%$ acetic acid. The absorbance $(600 \mathrm{~nm})$ of each well was determined with an automated plate reader (Bio-Rad Laboratories, Richmond, CA).

\section{Results}

Effects of TPA on TNF gene expression. TNF mRNA was undetectable by Northern analysis in resting monocytes (Fig. 1). However, TNF transcripts were detectable by $3 \mathrm{~h}$ after exposure of resting monocytes to $33 \mathrm{nM}$ TPA. The level of TNF mRNA reached a maximum by $12 \mathrm{~h}$ and then decreased to low but detectable levels. An increase in TNF mRNA was also observed after a 6-h exposure of resting monocytes to bacterial LPS $(1 \mu \mathrm{g} / \mathrm{ml})$.

Effect of protein synthesis inhibition on TNF gene expression. Resting and activated monocytes were exposed to $\mathrm{CHX}$ to determine if the level of TNF mRNA was regulated by the

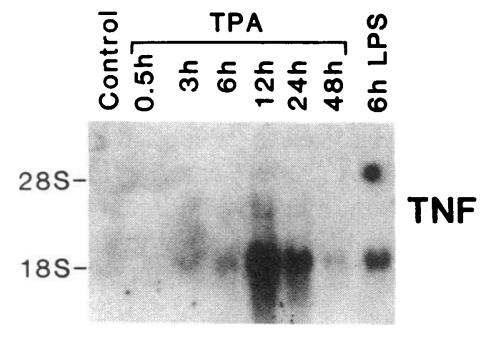

Figure 1. Kinetics of TNF mRNA induction after TPA treatment of resting human monocytes. Total cellular RNA was isolated from resting monocytes treated with TPA (33 $\mathrm{nM})$ or LPS $(1 \mu \mathrm{g} / \mathrm{ml})$ for the indicated periods of time. RNA (20 $\mu \mathrm{g})$ was analyzed and hybridized to a ${ }^{32} \mathrm{P}-\mathrm{la}$ beled human TNF cDNA probe.

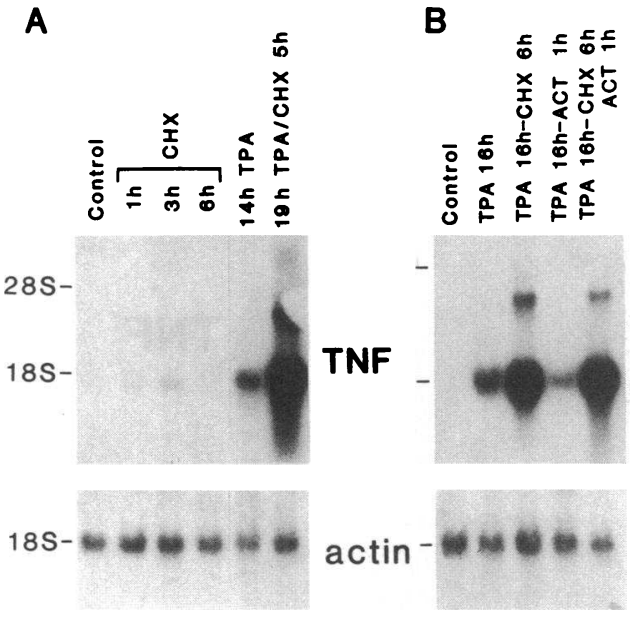

Figure 2. Effect of CHX on TNF gene transcription in resting and activated monocytes. $(A)$ Total cellular RNA was isolated from resting monocytes exposed to $\mathrm{CHX}(1 \mu \mathrm{g} / \mathrm{ml})$ for the indicated periods of time and from TPA $(14 \mathrm{~h})$ activated monocytes and from monocytes treated with TPA for $14 \mathrm{~h}$ and then TPA/CHX for an additional $5 \mathrm{~h}$. (B) Total cellular RNA was isolated from resting monocytes or monocytes exposed to TPA (33 nM), CHX (10 $\mu \mathrm{g} / \mathrm{ml})$ and ACT $(5 \mu \mathrm{g} / \mathrm{ml})$ as indicated. RNA $(20 \mu \mathrm{g})$ was analyzed as in Fig. 1. $\mathrm{CHX}$ was added after $10 \mathrm{~h}$ of TPA treatment and the cells were harvested $6 \mathrm{~h}$ later. Actinomycin D was added after $15 \mathrm{~h}$ of TPA treatment and the cells were harvested $1 \mathrm{~h}$ later.

synthesis of a labile protein. As shown in Fig. $2 A$, the addition of $\mathrm{CHX}(10 \mu \mathrm{g} / \mathrm{ml})$ to resting monocytes failed to induce a detectable level of TNF transcripts. In contrast, $\mathrm{CHX}$ increased the level of TNF mRNA in TPA-activated cells by $\sim 50$-fold. To further analyze whether this superinduction by CHX was related to transcriptional and/or posttranscriptional controls, activated monocytes were exposed to actinomycin $\mathrm{D}$. Exposure to actinomycin D $(5 \mu \mathrm{g} / \mathrm{ml})$ for $1 \mathrm{~h}$ decreased the level of TNF transcripts by $75 \%$ in these cells (Fig. $2 \mathrm{~B}$ ). In contrast, there was no detectable decrease in TNF mRNA when cells were exposed to $\mathrm{CHX}$ for $5 \mathrm{~h}$ and then to $\mathrm{CHX} / \mathrm{ac}$ tinomycin $\mathrm{D}$ for an additional $1 \mathrm{~h}$.

Similar results were obtained in a more detailed time course using freshly isolated or activated monocytes that constitutively express TNF. In this study, the monocytes were exposed to CHX, actinomycin D or the combination of these agents for 1, 3, and $6 \mathrm{~h}$. CHX was added $10 \mathrm{~min}$ before actinomycin $\mathrm{D}$ when cells were treated with both drugs. TNF mRNA levels decreased by $>90 \%$ after a 1 -h exposure to actinomycin $D$, thus indicating a half-life of $<20 \mathrm{~min}$ (Fig. 3). In contrast, there was no change in the level of TNF transcripts in cells treated with both $\mathrm{CHX}$ and actinomycin D for $1 \mathrm{~h}$. However, TNF mRNA degradation was not completely inhibited by $\mathrm{CHX}$, since these transcripts were undetectable after $3 \mathrm{~h}$ of exposure to both drugs (Fig. 3).

$T N F$ gene transcription rate in resting and TPA activated monocytes. In order to analyze whether the absence of TNF transcripts in resting monocytes was secondary to transcriptional or posttranscriptional mechanisms, we measured the rate of TNF gene transcription in isolated nuclei using the run-on transcription assay procedure. As shown in Fig. $4 A$, the TNF gene was transcriptionally inactive in resting monocytes. In control experiments, the beta actin gene was actively 


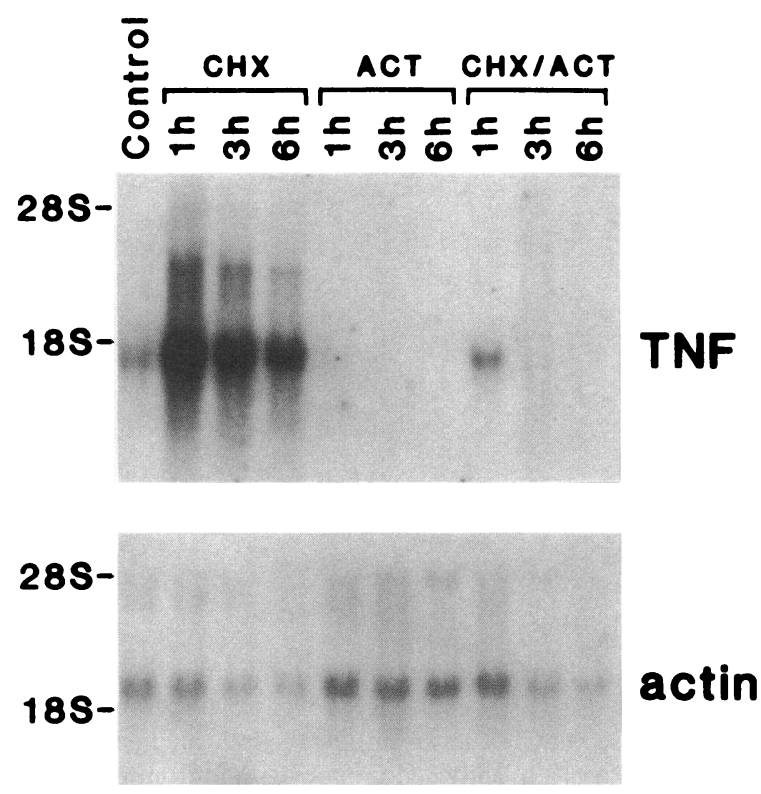

Figure 3. TNF mRNA levels in activated monocytes exposed to ACT, CHX or the combination of these agents. Freshly isolated and activated monocytes were exposed to ACT $(5 \mu \mathrm{g} / \mathrm{ml})$, CHX (10 $\mu \mathrm{g} / \mathrm{ml}$ ) or the combination of these agents for the indicated times. CHX was added 10 min before actinomycin $D$ when using both agents. Total cellular RNA was hybridized to the ${ }^{32} \mathrm{P}$-labeled human TNF cDNA or to a ${ }^{32} \mathrm{P}$-labeled chicken beta actin DNA probe.

transcribed in resting monocytes, while the beta globin gene was also transcriptionally inactive. In contrast, treatment of resting monocytes was associated with a rapid increase in TNF gene transcription, which was detected as early as $\mathbf{2 0}$ min after drug exposure.

TNF gene transcription was then compared in TPA and TPA/CHX-treated monocytes to determine whether transcriptional regulation was also responsible for the increase in
TNF transcripts in activated monocytes exposed to $\mathrm{CHX}$. As shown in Fig. $4 B$, TNF transcription activity increased 12-fold after $\mathrm{CHX}$ exposure. In contrast, the rate of c-src gene transcription remained unchanged under these experimental conditions.

Effects of TPA on TNF protein production. The effects of TPA on TNF protein production were determined by both ELISA and the L-cell cytotoxicity assay. TNF protein production in supernatants of resting monocytes treated with TPA was first detectable at $3 \mathrm{~h}$ (Fig. $5 \mathrm{~A}$ ). Furthermore, the level of TNF protein increased progressively during $15 \mathrm{~h}$ of TPA exposure (Fig. $5 \mathrm{~A}$ ). Culture supernatant from monocytes treated with TPA for $12 \mathrm{~h}$ was monitored for biological activity against TNF sensitive and resistant L-cells (17). The TNF-sensitive L-cells were progressively killed by adding increasing amounts of culture supernatant (Fig. $5 \mathrm{~B}$ ). In contrast, this supernatant had loss of a cytotoxic effect against the TNF-resistant L-cells (Fig. $5 \mathrm{~B}$ ). Moreover, pretreatment of the supernatant with a neutralizing anti-TNF monoclonal antibody resulted in a loss of cytotoxic activity against TNF-sensitive L-cells (Fig. $5 \mathrm{~B}$ ). Finally, there was no detectable production of TNF protein by ELISA or L-cell cytotoxicity assay in supernatants of untreated resting monocytes.

\section{Discussion}

The TNF gene is transcriptionally active and TNF mRNA is detectable by Northern analysis $(18,19)$ in thioglycollate elicited mouse macrophages. However, this TNF mRNA is not translated into protein (18), thus indicating that TNF gene expression is primarily regulated at the translational level in these cells. Our study indicates that TNF gene expression is controlled at the transcriptional level in resting human monocytes. Thus, in resting monocytes, TNF transcripts are undetectable and nuclear run-on transcription assays indicate that the TNF gene is transcriptionally inactive. However, a rapid induction in TNF gene transcription was observed as rapidly

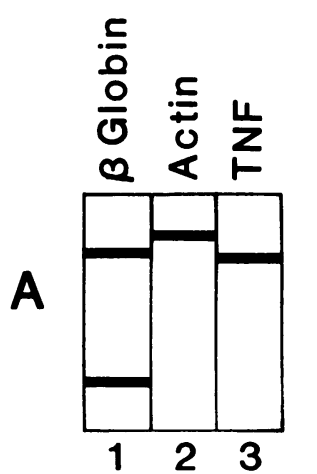

B

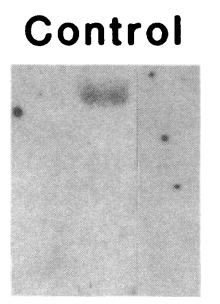

123

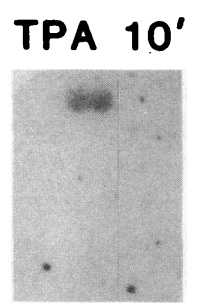

123

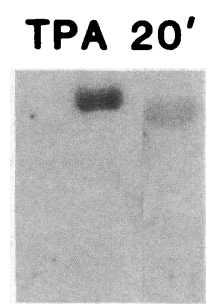

123

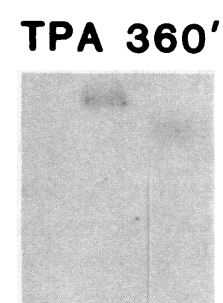

123
Figure 4. Analysis of TNF gene transcription in resting TPA-activated, and CHX-treated monocytes. Nuclei were isolated and run-on transcription assays were performed as described in Methods. $(A) 5 \mu \mathrm{g}$ of linearized beta globin, actin, and TNF plasmid DNA were run on a $1 \%$ agarose gel, transferred to nitrocellulose paper by Southern blot- . ting, and hybridized to similar amounts of ${ }^{32} \mathrm{P}$-labeled nuclear RNA $\left(10^{6} \mathrm{cpm} / \mathrm{ml}\right)$ isolated from resting monocytes and monocytes exposed for 10,20 , and $360 \mathrm{~min}$ to TPA. (B) $5 \mu \mathrm{g}$ of linearized beta globin, TNF and c-src plasmid DNA were spotted into nitrocellulose filters using a dot blot apparatus and hybridized to ${ }^{32} \mathrm{P}$-labeled nuclear RNA $\left(2 \times 10^{6} \mathrm{cpm} / \mathrm{ml}\right)$ isolated from monocytes exposed to TPA for $12 \mathrm{~h}$ and monocytes exposed to TPA for $12 \mathrm{~h}$ and $\mathrm{CHX}$ for $1 \mathrm{~h}$. 

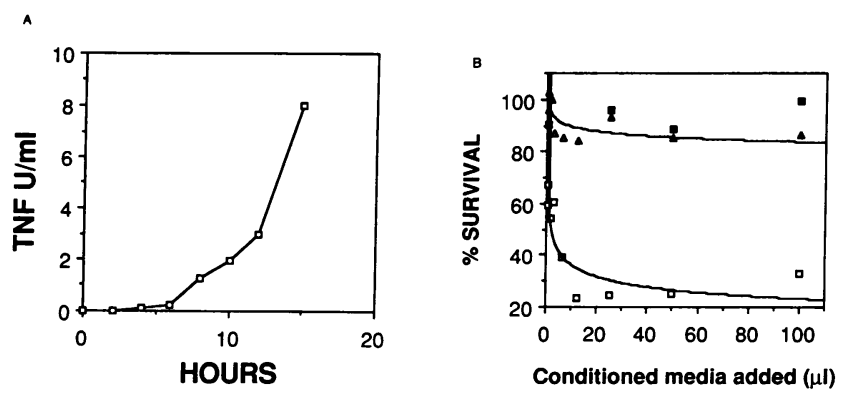

Figure 5. Effects of TPA on production of TNF protein by resting monocytes. $(A)$ Resting monocytes $\left(10^{6} /\right.$ well) were treated with 33 nM TPA for the indicated times and the supernatants assayed for TNF protein by ELISA as described in Methods. The results represent the mean of three determinations with a standard deviation of $10 \%$. (B) The supernatant from monocytes treated with TPA for $12 \mathrm{~h}$ was monitored for cytotoxic activity against TNF-sensitive ( $\square$ ) and resistant $(\Delta)$ L-cells. The total volume of the cytotoxicity assay was $200 \mu \mathrm{l}$. Supernatant from TPA-treated monocytes was also incubated with anti-TNF monoclonal antibody ( $\bullet$ ) before monitoring cytotoxic activity against the TNF-sensitive L-cells.

as $20 \mathrm{~min}$ after exposure of resting monocytes to TPA. This increase in TNF transcription was accompanied by the appearance of TNF transcripts that reached maximal levels by $12 \mathrm{~h}$ after TPA exposure. This TPA-induced increase in TNF transcription was also associated with release of TNF protein in the culture supernatant.

Our results agree with previous studies that demonstrated that: (a) peripheral blood monocytes do not produce detectable levels of TNF protein and do not exhibit spontaneous cytotoxicity against tumor cell targets (4-6); and (b) mononuclear cells exposed to TPA and endotoxin secrete TNF by $2 \mathrm{~h}$ after drug treatment and produce maximal TNF-specific cytotoxic activity by $30 \mathrm{~h}$ (4). Thus, the absence of TNF gene expression at the transcriptional level in resting monocytes is a major reason why these cells fail to exhibit spontaneous tumoricidal activity. In this regard, the ability of the combination of LPS and gamma interferon to induce cytotoxic activity in monocytes might be related in part to the ability of these agents to transcriptionally activate the TNF gene $(18,19)$.

The results of our study also indicate that once the TNF gene is transcriptionally active, posttranscriptional mechanisms operate to control TNF gene expression. Thus, $\mathrm{CHX}$, an inhibitor of protein synthesis, markedly increases the level of TNF mRNA in TPA-activated monocytes. This effect was related in part to stabilization of TNF transcripts since $\mathrm{CHX}$ prolonged the half-life of TNF mRNA in cells where transcriptional activity was blocked by actinomycin $\mathrm{D}$.

Of interest, the TNF gene, as well as other cytokines and certain proto-oncogenes, contain AU rich sequences in the $\mathbf{3}^{\prime}$ untranslated region of their mRNAs (20). Each of these gene products is expressed transiently. In contrast, the AU rich sequences have not been identified in genes known to express stable levels of transcripts (20). Consequently, these unique sequences may be recognition sites for mRNA processing pathways that degrade specific transcripts $(20,21)$. These pathways are sensitive to $\mathrm{CHX}$, thus indicating that labile proteins, probably RNases, are responsible for the short-life of these transcripts.

In addition to stabilizing TNF transcripts, $\mathrm{CHX}$ also increased TNF gene transcription in TPA-treated monocytes.
Similar results have been obtained in mouse macrophages (19). These findings suggest that TNF gene activation can also occur in the absence of protein synthesis and thus must involve the modification of preexisting cellular factors. This modification might increase the affinity of a nuclear factor for DNA binding or change the conformation of a factor already bound to a regulatory element controlling expression of the TNF gene. Modification of preexisting cellular factors has been investigated as a mechanism responsible for regulating expression of the heat shock, c-fos and steroid responsive genes (22). Different DNA binding proteins involved in the regulation of c-fos proto-oncogene expression have been characterized and found to be both cell and inducer specific (23). Since the TNF gene is expressed in different cell types and can be induced by different agents, it would be of interest to determine if: $(a)$ different cis-acting sequences and transcription factors regulate TNF gene expression, as already described for the $c$-fos gene; and $(b)$ these factors are specific for cell type and inducer.

\section{Acknowledgments}

Supported by U. S. Public Health Service grant CA-34183 awarded by the National Cancer Institute, Division of Health and Human Services, a NATO fellowship to Dr. Sariban, and a Burroughs Wellcome Clinical Pharmacology Scholar Award to Dr. Kufe.

\section{References}

1. Adams, D. O., and T. A. Hamilton. 1984. The cell biology of macrophage activation. Annu. Rev. Immunol. 2:283-318.

2. Beutler, B., J. Mahoney, N. Le Trang, P. Pekala, and A. Cerami. 1985. Purification of cachectin, a lipoprotein lipase-suppressing hormone secreted by endotoxin-induced RAW 264.7 cells. J. Exp. Med. 161:984-995.

3. Philip, R., and L. Epstein. 1986. Tumor necrosis factor as immunomodulator and mediator of monocyte cytotoxicity induced by itself, gamma-interferon and interleukin-1. Nature (Lond.). 323:8689.

4. Nedwin, G. E., L. P. Svedersky, T. S. Bringman, M. A. Palladino, and D. V. Goeddel. 1985. Effect of interleukin 2, interferon-gamma, and mitogens on the production of tumor necrosis factors alpha and beta. J. Immunol. 135:2492-2497.

5. Freundlich, B., G. Trinchieri, B. Perussia, and R. B. Zurier. 1984. The cytotoxic effector cells in preparations of adherent mononuclear cells from human peripheral blood. J. Immunol. 132:1255-1260.

6. Kornbluth, R. S., and T. S. Edgington. 1986. Tumor necrosis factor production by human monocytes is a regulated event: Induction of TNF-alpha mediated cellular cytotoxicity by endotoxin. $\mathrm{J}$. Immunol. 137:2585-2591.

7. Changellan, P. S., and D. T. Fearan. 1986. Tissue specific phosphorylation of complement receptors CR1 and CR2. J. Exp. Med. 163:101-115.

8. Vassali, J. D., J. M. Dayer, A. Wohlwend, and D. Belin. 1984. Concomitant secretion of prourokinase and a plasminogen activator specific inhibitor by cultured human monocytes-macrophages. J. Exp. Med. 159:1653-1668.

9. Mavier, P., and T. S. Edgington. 1984. Human monocyte-mediated tumor cytotoxicity. I. Demonstration of an oxygen-dependent myeloperoxidase-independent mechanism. J. Immunol. 132:19801986.

10. Chirgwin, J., A. Przybyla, R. MacDonald, and W. Rutter. 1979. Isolation of biologically active ribonucleic acid from sources enriched in ribonuclease. Biochemistry. 18:5294-5299.

11. Sariban, E., T. Mitchell, and D. Kufe. 1985. Expression of the 
c-fms proto-oncogene during human monocytic differentiation. $\mathrm{Na}$ ture (Lond.). 316:64-66.

12. Wang, A. M., A. A. Creasey, M. B. Ladner, L. S. Lin, J. Strickler, J. N. Van Arsdell, R. Yamamoto, and D. F. Mark. 1985. Molecular cloning of the complementary DNA for human tumor necrosis factor. Science (Wash. DC). 228:149-154.

13. Cleveland, D. W., M. A. Lopata, R. J. Mac Donald, N. J. Cowan, J. W. Rutter, and M. W. Kirschner. 1980. Number and evolutionary conservation of alpha- and beta- tubulin and cytoplasmic beta and gamma- actin genes using specified clones cDNA probes. Cell. 20:95-105.

14. Wilson, J. T., L. B. Wilson, J. K. de Riel, L. Villa-Komaroff, A. Efstratiadis, B. G. Forget, and S. M. Weisman. 1978. Insertion of synthetic copies of human globin genes into bacterial plasmids. Nucl. Acids Res. 5:563-581.

15. Gibbs, C. P., A. Tanaka, S. K. Anderson, S. Radul, J. Baar, A. Ridgway, H. S. Kung, and D. J. Fujita. 1985. Isolation and structural mapping of a human c-src gene homologous to the transforming gene (v-src) of Rous sarcoma virus. J. Virol. 53:19-24.

16. Hayashi, H., T. Kiyota, H. Sakamoto, and M. Seto. 1985. An enzyme-linked immunoabsorbent assay for recombinant human tumor necrosis factor using monoclonal antibody. In Recent Advances in Chemotherapy. J. Ishigami, editor. University of Tokyo Press. 820.
17. Rubin, B. Y., S. L. Anderson, S. A. Sullivan, B. D. Williamson, E. A. Carswell, and L. J. Old. 1986. Nonhematopoietic cells selected for resistance to tumor necrosis factor. J. Exp. Med. 164:1350-1355.

18. Beutler, B., N. Krochin, I. W. Milsark, C. Luedke, and A. Cerami. 1986. Control of cachectin (tumor necrosis factor) synthesis: Mechanisms of endotoxin resistance. Science (Wash. DC). 232:977981.

19. Collart, M. A., D. Belin, J. D. Vassali, S. de Kossodo, and P. Vassali. 1986. Gamma-interferon enhances macrophage transcription of the tumor necrosis factor/cachectin, interleukin I, and urokinase genes, which are controlled by short-lived repressors. J. Exp. Med. 164:2113-2118.

20. Caput, D., B. Beutler, K. Hartog, R. Thayer, S. Brown-Shimmer, and A. Cerami. 1986. Identification of a common nucleotide sequence in the $3^{\prime}$ untranslated region of mRNA molecules specifying inflammatory mediators. Proc. Natl. Acad. Sci. USA. 83:1670-1674.

21. Shaw, G., and R. Kamen. 1986. A conserved AU sequence from the 3 ' untranslated region of GM-CSF mRNA mediates selective mRNA degradation. Cell. 46:659-667.

22. Maniatis, T., S. Goodbourn, and J. A. Fischer. 1987. Regulation of inducible and tissue-specific gene expression. Science (Wash DC). 236:1237-1245.

23. Prywes, R., and R. G. Roeder. 1986. Inducible binding of a factor to the c-fos enhancer. Cell. 47:777-789. 